\title{
Özdemir YILMAZ"
}

\author{
ULUSLARARASI EĞİTIM VE TARİH \\ ARAŞTIRMALARI DERGISI \\ (ETA JOURNAL) \\ INTERNATIONAL JOURNAL OF EDUCATION AND \\ HISTORY RESEARCH \\ Yıl: 4, Sayı: 1, Ocak 2022, s. 68-85.

\section{NUMARALI MÜHIMME DEFTERİ ÖZELLİKLERİ, İÇERİĞİ VE DEĞERLENDİRILMESİ}

\begin{abstract}
ÖZET
Divân-1 Hümâyûn Osmanlı Devleti merkez teşkilatının en mühim müessesesi olup; üst düzey karar organıdır. Devletin siyasî, askerî, malî işleriyle meşgul olur, her türlü dava ve şikâyetlerle ilgilenir, karara bağlardı. Divân-1 Hümâyûn'da alınan kararlar, ferman, berat ve hükümlerin nakil kısmı Divân-1 Hümâyûn sicilleri olarak da bilinen mühimme defterlerine kaydedilirdi. Değerlendirmesini yaptı̆̆ımız 72 numaralı Mühimme Defteri, III. Murad (1574-1595) döneminin son zamanlarına ait olup; devrinin siyasî, askerî, malî, içtimaî vs. hadiseleri hakkında birçok malumatı ihtiva etmektedir. Defterde ağırlıklı birkaç konu bulunmaktadır ve bunlar; eşkıyalık olayları, İstanbul'a zahire nakli, Beç seferine asker naklidir. Çalışmada, Divân-ı Hümâyun, Mühimme Defterleri, 72 numaralı mühimme defteri ve defterde bahsi geçen III. Murad devri olayları hakkında genel bilgiler verilmiştir.
\end{abstract}

Anahtar kelimeler: Divân-1 Hümâyun, Mühimme Defterleri, 72 Numaralı Mühimme Defteri, III. Murad,

\section{THE PECULIARITY AND CONTENT OF MÜHIMME REGISTER'S NO:72 AND ITS ASSESSMENT}

Divân-1 Hümâyûn (Supreme Court in Ottoman Empire) is the most important institute of Ottoman Empire besides being a senior decision making body. It was engaged in political, martial and financial issues of the government and was responsible for every kind of lawsuit and complaint and made decisions about them. The decisions made in Divân-1 Hümâyûn, edict, charter and conveying section of the provisions were registered in the book of Mühimme, which is also known as the records of Divân-1 Hümâyûn. Numbered 72, the book of Mühimme belongs to the late period of Murat III (1574-1595) and involves a lot of information about political, martial, financial and social issues of the time. There are a few subjects that are stressed, and these subjects

\footnotetext{
${ }^{*}$ Doktora öğr., Atatürk Üniversitesi, Erzurum/ Türkiye, seyh_shamill@hotmail.com. ORCID: 0000-0002-4668-1900.

*Bu makale Turnitin programı ile taranmıştır.

*Araştırma makalesi.

*Makale geliş: 13.08.2021- Makale kabul: 25.11.2021.
} 
include incidence of banditry, supply of cereals and soldier transfer to Beç Campaingn. In this study, there are general accounts about Divân-1 Hümâyûn, The book of Mühimme and the events during Murad III period.

Key Words: Imperial Council, The book of Mühimme, The 72 numbers book of Mühimme, Murad III,

\section{GİRIȘ}

\section{DIVÂNI-I HÜMÂYUN VE MÜHIMME DEFTERLERİ}

\subsection{DIVÂN-I HÜMÂYUN}

Divân, kelimesi Türkçe'ye Arapça ve Farsça yoluyla geçmiştir. Kelimenin menşei itibariyle "Aramice" den geldiği ve Farsça'ya da bu dilden geçip yerleştiği kabul edilir. Divân eski İran'da mali kayıtların yazıldığı defterlere ve bu defterleri tutan resmi dairelere verilen isimdir. Divânın Farsça'da ilk, Arapça'da ikinci anlamı "kurul" veya "toplantı" dır. Osmanlılar'da ise divân "toplantı, kurul, kurul- organ" karş1lığında kullanılmıştır' .

Divân-1 Hümâyun'un kökeni Osmanlı Devleti'nden önce kurulan İslam, Türk ve Türkİslam Devletlerine dayanmaktadır. "Divân" kavramı, Hz. Ömer (634-644) halifeliği döneminde İslam devletine geçmiştir. Devletin artan gelirlerini belli bir düzene kavuşturmak amacıyla İran asıllı bir Müslümanın teklifiyle Divân teşkilatı hayata geçirilmiştir. Emeviler ve Abbasiler Dönemi'nde de divanlar devam ettirilmiştir. Özellikle Abbasi Devleti'nde Divân üyelerinin (vezir, kadü'l-kuzat vesair vazife sahiplerinin) yerleri belirlenmiştir. ${ }^{2}$

Doğu'da kurulan Türk- İslam Devletleri de, özellikle Gazneliler (963-1187) eski geleneklerinin de etkisiyle Abbasi divan sistemini devam ettirmiştir. Divân-1 Hümâyun'a benzeyen ilk Türk-İslam divanını Büyük Selçuklular kurmuşlardır. Divan-1 A'lâ adlı bu divanla Divân-1 Hümâyun'a geçiş süreci başlamıştır. Bu gelenek Anadolu Selçuklularında da devam etmiş ve daha sonra bu devletin parçalanmasıyla oluşan beyliklerde de divan geleneği sürdürülmüştür. ${ }^{3}$

Osmanlı Devleti'nde Orhan Bey döneminde Divân toplandığ 1 belirtilmektedir. Orhan Gazi devrinde Divân'a gelen beylerin başlarına burma sarık sardıkları yazılıdır. Tarih-i Saf'da Yıldırım Bayezid'in Bursa hisarında her gün "Bir âlî burçta oturup" halkın dertlerini dinlediği yazmaktadır. ${ }^{4}$ II. Murad(1421-1451) döneminde de Divân toplantıları devam etmiştir. Padişah II. Murad zamanında Divân toplantıları belirli bazı kaidelere bağlandığı gibi bir takım teşrifat kaideleri de konmuştur. Divân klasik yapısına ise Fatih Sultan Mehmet zamanında kavuşmuştur. Divân-1 Hümâyun adıyla anılması bu padişah dönemindedir. ${ }^{5}$ Fatih Sultan Mehmet zamanına kadar Divân'a padişah başkanlık etmekte iken onun saltanatında bu usul bırakılmış, toplantılar veziriazam başkanlığında yürütülmeye başlanmıştır. ${ }^{6}$ Padişah toplantıları tamamen terk etmeyip, Divânhaneye nazır "Kasr-1 Adl" adı verilen kafesli bir bölme arkasından toplantıları izlemeye devam etmiştir. XVII. yüzyıl ortalarından itibaren sadrazamların kendi konaklarında yaptıkları Divân önem kazanmıştır. XVII. yüzyılda "Paşa Kapısı" daha sonraları ise "Bâb-1 Âli" adıyla anılan merkez, kısa zamanda bütün devlet

\footnotetext{
${ }^{1}$ Ahmet Mumcu, "Dîvân-1 Hümâyun", DİA, C. IX, İstanbul 1994, s. 430.

${ }^{2}$ Ahmet Mumcu, Divan-ı Humayun, Birey ve Toplum Yay., Ankara 1986, s. 11-13.

${ }^{3}$ Mumcu, a.g.e., s.15.

${ }^{4}$ İ. Hakkı Uzunçarşıll, Osmanlı Devleti'nin Merkez ve Bahriye Teşkilatı, TTK. Yay., Ankara 1988, s.1.

${ }^{5}$ Recep Ahıshalı, "Divân-1 Hümâyûn Teşkilatı", Osmanlı, Yeni Türkiye Yay., Ankara 1999, IV, 24.

${ }^{6}$ Uzunçarşı1l, a.g.e, s. 2-3.
} 
işlerinin görüldüğü yer haline gelmiş ve Divân-1 Hümâyun'un önemi azalmıştır. III. Selim zamanında ise "Meşveret Meclisi" devlet işlerinin görüldüğü yer olmuştur. XIX. yüzyılda önemini tamamen yitiren Divân-1 Hümâyun sadece elçilerin ağırlanması, ulufe dağıtımı ve yeni tayin edilen devlet ricâlinin eskiden beri süre gelen bir adet olarak padişah tarafindan arzlarda kabulü merasiminden ibaret kalmıştır. ${ }^{7}$

Orhan Bey zamanından Fatih'in ilk dönemlerine kadar her gün toplanan Divân-1 Hümâyun, XVI. yüzyıldan itibaren haftada dört gün, XVII. yüzyıl ortalarında haftada iki gün, XVIII. yüzyıl başlarında, III. Ahmed zamanında haftada bir gün toplanmaya başlamıştır. ${ }^{8}$

Divân-1 Hümâyun'da daimi olarak bulunan görevliler şunlardır;

1- Veziriazam

2- Diğer kubbe vezirleri

3- Rumeli ve Anadolu kazaskerleri

4- Defterdarlar

5- Tevkiî veya Nişancı

Divân'da bu görevlilerin oturmaları için özel yerler belirlenmiştir. Bunlardan başka divanda, ayakta hizmet gören reisülküttap, çavuşbaşı ve kapucular kethüdası da yer almıştır. ${ }^{9}$

Divân-1 Hümayun üyelerinin her biri farklı yetkilere sahiplerdir. Veziriazam; padişahın mutlak vekili olarak II. Mehmet döneminden itibaren Divâna başkanlık etmeye başlamıştır. Bütün yetkilerini padişahtan alır, yasama, yürütme ve yarg1 ile ilgili alanlarda bu yetkiyi kullanırd1. Vezirler; önemli meselelerde sadrazamın sorması halinde fikirlerini beyan ederlerdi. Kadısker; askerî sınıfa ait davalar, veraset işleri, bazı hukukî ve şerî davalara bakarlardı. Nişancı; tevkiî, tuğraî de denir. Görevleri önemli fermânları yazmak, reisülküttap tarafindan yazılan fermanların tashih ve kontrolünü yapmak, fermanlar üzerine padişahın tuğrasını çekmek, örfi hukukla ilgili kanunları tespit etmekti. Defterdar; Padişahın malının mutlak vekilidir. Maliyeye ait meselelerde hüküm yazabilmek, çeşitli kimselere çavuşluk, sipahilik, kâtiplik, sancak ve zeamet verilmesini sadrazama teklif edebilme yetkilerine sahip idi. ${ }^{10}$

XVI. yüzyıl baslarından itibaren Divân-1 Hümayûn devlet içinde padişahtan sonra en önemli yeri almıştır. Bu durum XVII. yüzyıl sonlarına kadar sürmüş, bu dönemlerden başlayarak Divân-1 Hümâyun'un yetkileri yavaş yavaş veziriazam Divânına (İkindi Divânı) geçmeye başlamıştır. Divân-1 Hümayûn arada bir canlanmasına rağmen XVIII. yüzyıl ortalarında Bâb-1 Âsafî yani veziriazam dairesinin her bakımdan gelişmesi nedeniyle eski canlılığını yakalayamamıştır. II. Mahmud döneminde yapılan değişiklikler ile kabine sistemine geçilmiştir. Buna rağmen teşrifatta Divân-1 Hümayûn yerini korumuş olup ancak

\footnotetext{
${ }^{7}$ Ahıshali, a.g.e, s. 25.

${ }^{8}$ Yusuf Halaçoğlu, XIV. ve XVII. Yüzyıllarda Osmanılıarda Devlet Teşkilâtı ve Sosyal Yapı, T.T.K., Ankara 2003, s.8.

${ }^{9}$ Tevfik Temelkuran, "Divân-1 Hümâyun Mühimme Kalemi”, İsanbul Üni. Tarih Enst. Dergisi, S. 6, 1975, s. 132.

${ }^{10}$ Uzunçarşı1lı, a.g.e, s. 14.
} 
hukuki ve siyasi fonksiyonu devam etmemiştir. ${ }^{11}$

\subsection{MÜHİMME DEFTERLERİ}

Eski Türk devlet ananesinde basit şekillerde görülen Divân sistemi, bilhassa İslam devletlerinde oldukça gelişmiş ve bu sistem teşkilatının ana yapısını kendisinden önceki Türk ve İslam devletlerinden tevarüs eden Osmanlılara, muhtemelen Anadolu Selçuklularından geçmiştir. Osmanlı Devleti'nin hızla büyümesine paralel olarak devletin idari yapısı şekillenmeye başlamış, dolayısıyla II. Murad ve özellikle Fatih Sultan Mehmet zamanında divân sistemi, teşrifat kaidelerinin tespitiyle müesseseleşmiş ve XVI. asırdan itibaren de bilinen klasik yapısına kavuşmuştur. Divân-1 Hümâyûn'un çalışma tarzı ve fonksiyonunu aydınlatmaya yardımcı olan en önemli kaynaklar mühimme defterleridir. ${ }^{12}$

Bugün Başbakanlık Osmanlı Arşivi'nde "Mühimme Defterleri” adıyla kayıtlı defter serisi mevcuttur. Bu başlık altında tasnife açık olan defter sayısı, son yıllarda bulunanlarla birlikte toplam 267 adettir (961-1323/1553-1905 y1llar1 aras1). Son tespit edilen 267 numaral1 defter XVIII. yüzyıl ikinci yarısına aittir. Ayrıca XVII. yüzyıl başlarına ait bir defterin henüz restorasyon servisinde olduğu ve tasnife dahil edilmediği bildirilmektedir. Yine restore edilecek belgeler arasında sonradan bulunan Mühimme defteri parçaları da vardır. ${ }^{13} \mathrm{Bu}$ defterlerden ilk 73 defterin hüküm özetlerinden oluşan hülasa katalogları ve 21-28, 119, 260 ve 261 Numaralı Mühime Defterinin indeksi mevcuttur. Bunun yanında 3, 5, 6, 7 ve 12 Numaralı Mühime Defterleri Osmanlı Arşivi tarafından tıpkıbasım ve indeksli olarak basılmıştır. Bu 267 Mühimme Defteri içerisinde 20 Numaralı Mühimme Defteri mevcut değildir. ${ }^{14} \mathrm{Bu}$ tasnifteki defterlerin 13 tanesi klasik mühimme değildir. Geriye kalan defterlerden bazılarının da maliye ahkâmı ve şikâyet defteri oldukları görülmektedir. ${ }^{15}$ A.DVN.MHM. koduyla oluşturulan bir başka tasnifte de H. 977-1252/M. 1570-1836 yıllarının ihtiva eden çoğu birkaç sayfa ya da formadan oluşan 43 adet mühimme defteri parçası vardır. Mühimme defterleri tasnifi yapıldıktan sonra yeni bulunan defterlerden oluşturulan mühimme zeyli defterleri tasnifinde H. 980-1195/M. 1572-1780 y1llar1 arasındaki kayitlara muhtevi 17 defter bulunmaktayken ${ }^{16}$, bu seriden 17 numaralı defter sonradan Nâmei Hümâyûn tasnifine aktarılmıştır. ${ }^{17} 986$ Numaralı Kamil Kepeci (KK) tasnifinde H. 9271168/M. 1520-1658 tarihleri arasındaki kayıtları içeren eden 61-73 genel numaralarda kayıtlı 13 adet Ahkâm Defteri mevcuttur. ${ }^{18}$ Başbakanlık Osmanlı Arşivi’nden başka Topkapı Sarayı Müzesi Arşivi ve Köprülü Kütüphanesi'nde de mühimme defteri mevcuttur. ${ }^{19}$

Osmanlı merkez karar organı olan Divan-1 Hümâyun'da dahili ve harici meselelere ait siyasi, askeri ve sosyal önemi haiz birçok konunun müzakere edilip karara bağlandı $\breve{g} 1$

\footnotetext{
${ }^{11}$ Mumcu, a.g.m., s.431.

12 İsmet Miroğlu, "Mühimme Defterleri", Tarih ve Medeniyet Dergisi, S. 12, İstanbul 1993, s.58

${ }^{13}$ Feridun, Emecen, "Osmanlı Divânının Ana Defter Serileri: Ahkâm-1 Miri, Ahkâm-1 Kuyudu Mühimme ve Ahkâm-1 Şikâyet”, Türkiye Araştırmaları Literatür Dergisi, C. 3, S. 5, 2005, s.108.

${ }^{14}$ Başbakanlık Osmanlı Arşivi Rehberi, s. 10-11.

${ }^{15}$ Emecen, a.g.m., s. 108.

${ }^{16}$ Başbakanlık Osmanlı Arşivi Rehberi, s. 18.

${ }^{17}$ Emecen, a.g.m., s. 109.

18 Başbakanlık Osmanlı Arşivi Rehberi, s. 25.

19 Emecen, a.g.m., s. 109-110.
} 
defterler olan mühimme defterlerinde ${ }^{20}$ açıklandığı üzere bir çok konuya ait hükümler bulmak mümkündür. Başlangıçta Divân-1 Hümâyun tarafindan verilen kararlara dair her çeşit ferman mühimme defterlerine kaydedilmiştir. Bu kayıtlar tarih sırasına göre yapıldığı için Divân toplantılarının günlerini tespit etmek mümkündür. Mühimme Defterlerindeki kayıtlara göre 1649 (1059) tarihinden itibaren bütün ferman kayıtlarının mühimme defterlerine yapılmadığ 1 görülmektedir. Devletin idari, siyasi, askeri meselelerin dışında halkın devlet ile münasebetlerine dair konular için ayrı defterler tutulmaya başlanmıştır. Bunlar daha çok şikâyet ve dilek mahiyetinde konular olduğundan bu defterlere, "şikâyet defterleri" adı verilmiştir. Şikâyet defterleri de 1742 tarihinden itibaren eyalet eyalet ayrılarak, "ahkâm-1 şikâyet" ya da "ahkâm defterleri" adını almıştır. Şikâyet türünün yanı sıra 1699 yılında nâme-i hümâyunlar, 1707'de Misır eyaletine gönderilen fermanlar, 1747'de Kalebent hükümleri, 1787 'de gizli emirler, 1863 'te mülki tevcîhat, 1869 'da makine fabrika imtiyazı ve kilise kayıtları Mühimme Defterlerinden ayrılarak başka defterlere kayıt edilmiştir. ${ }^{21}$

Mühimme Defterleri, hükümlerin verildiği divanlara göre dört grup halinde değerlendirilir.

1- Mühimme: Padişah ve sadrazam İstanbul'da olduğunda sadrazam başkanlığındaki divan toplantılarının hükümlerinin kaydolduğu defterlerdir.

2- Rikâb mühimmesi: sadrazam sefer veya başka bir nedenle İstanbul dişında olduğunda yerine bıraktığı rikâb kaymakamı veya sadaret kaymakamı başkanlığındaki divan toplantıların hükümlerinin kaydolduğu defterlerdir.

3- Ordu mühimmesi: Ordu ile sefere çıkan sadrazam seferdeyken yaptığı Divân toplantılarındaki hükümlerin kaydolduğu defterlerdir.

4- Kaymakamlık mühimmesi: Hem Padişah hem de sadrazam İstanbul dişına çıktığında tayin edilen kaymakam başkanlığında yapılan divan toplantılarındaki hükümlerin kaydolduğu defterlerdir. ${ }^{22}$

Ayrıca devlet yönetimi açısından çok gizliliği olan özel önemdeki hükümlerin kaydedildiği mektûm mühimmesi'nin sayısı onu geçmemektedir. Mısır'ın merkezden uzak olması ve bölgesinde önemli bir mevkide olma eğilimini kazanmasından dolayı divan oluşumu kendiliğinden meydana gelirken burada görüşülen konularla mühimme-i Misır adlı defterler oluşmuştur. ${ }^{23}$

72 numaralı mühimme defteri muhteva bakımından Osmanlı Devleti'nin merkez ve taşra teşkilatındaki idari ve askeri organlarıyla yazışmaları, ayrıca komşu ülkeler ile olan münasebetler, halkın sosyal ve ekonomik konularını, eşkıyalık olayları gibi birçok konuyu içermesi ile yapısal özellikleri bakımından bir klasik divan mühimmesidir denilebilir. ${ }^{24}$

\footnotetext{
${ }^{20} 3$ Numaralı Mühimme Defteri (966-968/i 558-i 560), T.C. Başbakanlık, Devlet Arşivleri Genel Müdürlüğü Ankara 1993, s. XXI.

${ }^{21} 44$ Numaralı Mühimme Defteri, (Haz. Mehmet Ali Ünal), Akademi Kitabevi Yay., İzmir 1995, s. VI.

${ }^{22}$ M. Zeki Pakalın, Osmanlı Tarih Deyimleri ve Terimleri Sözlüğü, C.II, İstanbul 1993, s. 695.

${ }^{23}$ Uzunçarşıll, a.g.e., s. 82

${ }^{24}$ Selanik-î Mustafa Efendi, Tarih-i Selanik-î, 409-412.
} 


\section{72 NUMARALI MÜHIMME DEFTERININ ÖZELLIKLERİ}

\subsection{DEFTERIN FİİKî DURUMU}

Başbakanlık Osmanlı arşivinde A.DVN.MHM. d.072 şeklinde kayıtlı olan defter 236 varak 471 sayfadan ibarettir. 466 yazılı 5 boş sayfadan oluşmaktadır. Defterde tamamı numaralı 909 hükmü bulunmaktadır. ${ }^{25}$

Yazı genel olarak divâni kırma olup okunaklıdır. Fakat bazı hükümlerin üzerinin çizilmesi, hüküm yanlarına ekler yapılması, mürekkebin dağılması okumayı oldukça zorlaştırmaktadır. ${ }^{26}$ Defterin hüküm ve sayfa numaraları daha sonradan eklenmiş olup orijinal değildir. Deftere sayfa ve hüküm numaraları verilirken sondan başa doğru verilmiştir; Defterin ilk hükmü 3 Safer ul-muzaffer sene 1003 iken son hükmü 1 Recebü'l-mürecceb 1002'dir. Sayfa numaraları verilirken 6 ve 7 numaralar atlanmış hükümlere 11 numara iki kez verilmiş 10 numara atlanmıştır. ${ }^{27}$

Bir sayfada genel itibarıyla iki hüküm var iken, bu sayı bazı sayfalarda bire düşmüş ${ }^{28}$ bazı sayfalarda da üçe çıkmıştır. ${ }^{29}$ Sadece iki sayfasında dört hüküm vardır. ${ }^{30}$ Defterde yer alan en uzun hüküm Vezir Cafer Paşa'ya gönderilen 279 numaralı hüküm iken, ${ }^{31}$ en kısa hüküm ise Magosa Beyine gönderilen 114 numaralı hükümdür. ${ }^{32}$ Defterdeki bazı hükümler yarım bırakıldıktan, ${ }^{33}$ bazı hükümler ise tamamlandıktan sonra iptal edilmiş, ${ }^{34}$ bazı hükümler de iptal edilmeden yarım bırakılmıştır. ${ }^{35}$ Genel olarak bütün hükümler sayfada düz bir şekilde yer alsa da bazı hükümlerde özellikle tarihler sayfa yapısına paralel olarak yazılmış, ${ }^{36}$ bazı hükümlerin bir kısmı düz yazılırken küçük bir kısmı da yan bir şekilde yazılmıştır. ${ }^{37}$ Defterde yer alan ilk hüküm, ${ }^{38}$ Çirmen Beyine ve Kadılarına gönderilen hüküm olup, son hüküm ise Vilayet-i Rum Kadılarına gönderilen hükümdür. ${ }^{39}$

\subsection{DİPLOMATIK ve TEKNIK ÖZELLIKLER}

Divânda müzakere sonucu alınan kararların sureti divân kâtipleri tarafindan yazılır ve reisülküttap tarafından gözden geçirilir, doğrulanır daha sonrada ilgili yere tuğra çekilerek yollanır, müsvedde kayıtlar defterde yer alırdı. Bunlar genellikle müzakere sırasında değil sonradan kaydedilirdi. ${ }^{40}$ Bir şikâyet yahut arz karşılı̆g 1 doğrudan divanın kararı üzerine buna uygun bir metin taslağı hazırlanır, gerekiyorsa üzerine düzeltmeler yapılır, bu işlemler

\footnotetext{
25 A.DVN.MHM. d.072

${ }^{26}$ A.DVN.MHM. d.072, Hüküm 2, 28, 53, 256, 258.(Bundan sonraki dipnotlarda sadece hüküm numaras1 verilecektir).

27 A.DVN.MHM. d.072.

${ }^{28}$ Hüküm 1, 2, 8, 9, 11, 12, 16, 129,168, 173, 174, 205, 221.

${ }^{29}$ Hüküm 13-15, 17-19, 20-22, 179-181, 209-211, 295-297.

${ }^{30}$ Hüküm 92-96, 151-154.

${ }^{31}$ Hüküm 279.

${ }^{32}$ Hüküm 114.

${ }^{33}$ Hüküm 79.

${ }^{34}$ Hüküm 60, 68, 71, 87, 120, 125, 140, 163, 168, 172, 209, 234, 243, 244.

${ }^{35}$ Hüküm 6, 130, 200, 217.

${ }^{36}$ Hüküm 7, 22, 41, 43, 45, 53, 60, 78, 118, 121, 124, 126, 239.

${ }^{37}$ Hüküm 2, 28, 53, 70, 256, 258, 298.

${ }^{38}$ Hüküm 1.

${ }^{39}$ Hüküm 302.

${ }^{40}$ Uzunçarşıl1, a.g.e., s. 79-80.
} 
sırasında metin taslağının düzeltilmiş şekilleri bir araya getirilerek mühimme defterlerine kaydedilir. Bir bakıma mühimmeye kaydedilen suretler son aşamada fermanın gönderilmesinden hemen öncesine aittir. ${ }^{41}$

Mühimme Defterleri; gönderilen fermanların suretlerini ihtiva ettiği için fermanlarda bulunan tuğra ve davet gibi bölümler mühimmelerde yer almamasına rağmen, yine de belgelerde yer alan rükünlerin büyük bir kısmını kapsamaktadır.

Padişaha ait olan belgeler içerisinde bulunan fermanlardaki rükün ve şartları şunlardır. ${ }^{42}$

- Davet

- Tuğra

- Elkab

- Dua

- Nakil-iblağ

- Emir-Hüküm

- Te'kid-Tehdid

- Tarih

- Mahal-i Tahrir

$\mathrm{Bu}$ itibarla defterdeki hükümlerin tamamında hitap kısmıyla başlanmıştır. Bu bölümde hükmün gönderildiği kişi ve görevi ya da yalnızca görevi yer almıştır. Ayrıca aynı hüküm farklı bölgelere, farklı kişilere de gönderildiği de olmuştur. "Boğdan Voyvodası'na hüküm ki"43, "İstânbûl Kadîsı'na ve Koyun Nazırl’na ve Koyun Emini’ne hüküm ki”,44, " Şam Yeniçerileri Ağasına hüküm ki ",45, “ Konya Kadîsı’na ve Karaman Beylerbeyisi'nin Müsellemine hüküm ki"46, "Kayseriyye beyine hüküm ki"47, "Zülkadiriyye Beylerbeyi'sine hüküm ki "48, "Iç̧-il Beyine hüküm ki", gibi; birkaç belge ise name-i hümayun olup biraz farkl11ık göstermektedir "Mekke-i Mükerreme şerîfine name-i hümâyûn ki" ${ }^{49}$, "Erdel voyvoda name-i hümâyûn olınırki" ${ }^{\text {,50 }}$ ifadeleri yer alırken "buyurdum $k i$ ", ifadesinin yerini "gerekdir $k i{ }^{\prime}{ }^{52}$ ifadesi almıştır.

Hitap bölümünü müteakip emrin yazılmasına neden olan durumun ve olayın anlatıldığ nakil-iblağ rüknüne geçilmektedir. "Südde-i Sa'âdetimde topçular kethüdası olan Mustafa

\footnotetext{
${ }^{41}$ Emecen, a.g.m., s. 130.

${ }^{42}$ Mübühat S. Kütükoğlu, Osmanlı Belgelerini Dili (Diplomatik), Kubbealtı Neşriyatı Yay., İstanbul 1994, s. 100-116.

${ }^{43}$ Hüküm 84.

${ }^{44}$ Hüküm 85.

${ }^{45}$ Hüküm 184.

${ }^{46}$ Hüküm 185.

${ }^{47}$ Hüküm 199.

${ }^{48}$ Hüküm 221.

${ }^{49}$ Hüküm 129.

${ }^{50}$ Hüküm 216.

${ }^{51}$ Hüküm 1, 2, 3, 4.

${ }^{52}$ Hüküm 53, 75, 129.
} 
Südde-i Sa'âdetime mektûb gönderüp....."53, "Senki Haklu Kadîsisin südde-i sa'âdetime mektûb gönderüb..." "54 "Nefs-i Sakız'da olan Müslümanlar tarafindan dergâh-ı mu'allâma arz-ı hal sunılub..." 55 gibi ifadeler ile başlayan bu bölümde emrin yazılmasına sebep olan olaylar ya da durumlar çok fazla detaya girilmeden emrin muhatabına izah edilmiştir. Bu kısımda hükümlerin asıl sûretlerini içeren fermân vb. belgelerde olduğu gibi her devlet görevlisinin makamına göre isminden önce gelen bir elkâbı yer aalmıştır. Fakat belirtmek gerekir ki; burada yer alan elkâblar da hükmün kendisi gibi elkâb formülünün kısa bir bölümünü içermiştir. Örneğin defterde vezirler için "Düstûr-i mükerrem müş'îrmufahham", K6 Kırım Hanı için "Cenab-ı emâret meâb"57 Beylerbeyiler için "emîrü'lümerâi'l-kirâm" "58 elkâbları kullanılmıştır.

Defterde kişilerin isimlerinden sonra yine onların mevki ve mertebelerine göre küçük bir dua cümlesi yer almıştır. Beylerbeyiler için "dâme-ikbâlehû", ${ }^{59}$ müteveffa padişahlar için " tâbe serâhu”,"60 hazine emini, kâtip ve çavuşlar için "zîde kadruhû",;1 müteferrikalar için "zîde-mecduhû", ${ }^{2}$ ulemadan biri için "dâme-izzuhû" duaları kullanılmıştır. Nakil-iblağ bölümünü buyurdum ki ifadesiyle sona ererken "vardukda"63 veya "vusul buldukda"64 ibareleriyle emir-hüküm bölümüne geçilmiştir. Hükmün yazılmasına neden olan olay ya da durum özetlendikten sonra, bu konuda verilen emrin şer-i şerif mucibince yapılması gerekenler anlatılmıştır.

Hükümler bazen te'kid-tehdid rüknüyle sona ermektedir. Defterde bulunan “özrünüz makbul olmayub alınmağla konulmayub eşedd-i ikâba muakıb olmanuz mukarrerdir" 65, "koyunu doğru İstânbûl'a göndermeyüb ihmâl ü müsâhelenüz sebebi ile etrâf ve cevanibde olan kazâ ve mezraya dă̆llub anda boğazlayub satulduğu istima' olına azl ile konulmayub eşhedi "itab ve 'ikayla mua'tab ve mu'akıb olmanuz mukarrerdir" "66 rükunlar bunun örnekleridir.

Defterde bazı hükümlerin altlarında ilgili hükmün kimlere ya da hangi mahallere gönderildiklerini belirten sûret kayıtlarına da yer verilmiştir. "Bir süreti Trablusşam ve Şam Beylerbeyisine "67, “ bir sureti bir sureti Koca ili beyine Gelibolu'dan zu'amâ ve erbâb-ı tîmâr alaybeyleri ile müretteb ve mükemmel düşmen yerâğ ile hazır ve müheyya olub mahal-i mezbûrda gemiye girüb deryaya tevcîh etmek içün Kapudan Pâşâya hitaben sarahatle ile yazıla." 68 şeklinde ifadelerden anlaşıldığı gibi bu hükmün, ilk kısmında yazılan muhataptan

\footnotetext{
${ }^{53}$ Hüküm 141.

${ }^{54}$ Hüküm 142.

${ }^{55}$ Hüküm 160.

${ }^{56}$ Hüküm 33.

${ }^{57}$ Hüküm 152.

58 Hüküm 199.

${ }^{59}$ Hüküm 158.

${ }^{60}$ Hüküm 29.

${ }^{61}$ Hüküm 160.

${ }^{62}$ Hüküm 163.

${ }^{63}$ Hüküm 1, 4, 7.

${ }^{64}$ Hüküm 2, 3, 5, 6 .

${ }^{65}$ Hüküm 74.

${ }^{66}$ Hüküm 12.

${ }^{67}$ Hüküm 63.

${ }^{68}$ Hüküm 74.
} 
başka kimlere gönderilebileceğini belirtilmiştir.

Defterde yer alan hükümlerin üzerlerinde yer alan şerhler diplomatik açıdan oldukça önemli bilgiler vermektedir. Hükümlerin sağ üst köşesinde genellikle hükmü yazan kâtibin rumuzu ve üzerinde de görüldü anlamına gelen (//) işreti, hükmün tam üzerinde kâğıdı ortalar bir şekilde yazılmış, "buyruldu” ibaresi ve sol üst köşede ise kâtiblerin ya isimleri ya da onları simgeleyen rumuzlar bulunmaktadır. ${ }^{69}$ Katiblerin her birinin ayrı ayrı rumuzlar kullanmaları, yazdıkları hüküm, berat gibi kayıtların kimin tarafından hazırlandığının belirlenmesi ve herhangi bir karışıklığa meydan verilmemesi düşüncesinden kaynaklanmıştır. ${ }^{70}$

Hükümlerin üzerlerinde bulunan bazı şerhlerden hükümlerin veriliş sebebi ve şekli ile ilgili bilgiler elde etmek mümkündür. Örneğin o hükmün bizzat padişah tarafindan verildiği ve kati surette yerine getirilmesi gerektiğini ifade eden "hatt-ı hümayun" ibaresi en çok görülen kelimedir. ${ }^{71}$

Hükümlerin üzerinde yer alan diğer şerhler ise hükümlerin gönderildiği kişiler ile ilgilidir. "Kazâ-ı mezbûre sakinlerinden Ali Çavuş mübaşir ta yîn olınub Hükm-i Hümâyûn Ahdi verilmişdir""72, "Hevace ademi Mustafa çavuşa virilmişdir". 73

72 numaralı mühimme defteri içeriği itibarıyla Erzurum, Anadolu, Rum, Diyarbakır, Bağdat, Halep, Şam, Kıbrıs gibi geniş bir coğrafyaya gönderilen hükümleri ihtiva edip, içerisinde veziriazam, beylerbeyi, sancakbeyi, müderris, kadı, dizdar, defterdar, kâtip, emir-i hacc gibi birçok yöneticiye yazılmış hükümler yer almaktadır.

\subsection{DILL ÖZELLIKLLERI}

Defter genel olarak açık ve sade bir Türkçeye sahip olmasına rağmen günümüzde ender kullanılan ya da hiç kullanılmayan kelimeler, özellikle terkipler ve tamlamalar oldukça sık yer almıştır. Günümüz Türkçesinin dil özelliklerinden oldukça farklıdır. Mesela "görilüb “dutub”, “idüb”, "girü", “olınmağla”, "getürüb” gibi eylem ârz eden kelimelerin ekleri ve ifade ettiği anlam günümüzden oldukça farklıdır. Ancak bazı kelimelerin yazılışında da birtakım tutarsılılklar görülmektedir. "alıb- alub" "74, "getürüb-getürib"75, "için-içün"76, "vardukda-vardıkda" 77 , gibi ünlü değişiklikleri bunlardan sadece birkaçıdır.

Defterde dikkat çeken hususlardan birisi de bazı kelimelerin bazen Türkçe, bazen de Arapça ve Farsça karşılıklarının tercih edilmiş olmasıdır. Defter içerisinde "fesâd ve şenâat", zûlm ve teâddî", 78 "salb ve siyaset",79 örneklerinde olduğu gibi kelimeler Arapça ve Farsça

\footnotetext{
${ }^{69}$ Selçuk Demir, 75 Numaralı Mühimme Defteri, (Yayınlanmamış Yüksek Lisans Tezi), Atatürk Üniversitesi Sosyal Bilimler Enst., Erzurum 2008, s. 28.

${ }^{70}$ Feridun Emecen, “Ali’nin 'Ayn'ı: XVII. Yüzyıl Başlarında Osmanlı Bürokrasisinde Kâtib Rumuzları”, Osmanlı Klasik Çağında Hanedan Devlet ve Toplum, Timaş Yayınları, İstanbul 2011, s. 159

${ }^{71}$ Hüküm 2, 90, 124, 214.

72 Hüküm 32.

73 Hüküm 128.

74 Hüküm 1, 165.

75 Hüküm 122, 180

76 Hüküm 157, 159.

77 Hüküm 160, 236.

78 Hüküm 252, 254, 257.

79 Hüküm 1, 285.
} 
dillerindeki karşıllkları ile yer bulmuştur. Defterde terimlere de yer verilmiştir ve bu terimlerin hükümdeki mesajı güçlü hale getirdikleri düşünülmektedir. "dava-yı hakk ve tayini madde eylemek" 80 , "var kuvveti pazuya himmete getirmek" "11, "muceb-i ibret olmak",2, "ata ve dona kadir olmak" ${ }^{\prime 3}$ kullanılan terimlerin bazılarıdır.

\subsection{TARIHLER}

Birkaç istisna dışında XVII. yy. ortalarına, Sultan İbrahim saltanatına kadar tarihler ayın tarihi ile birlikte haftanın günüde gösterilmek üzere yazılmıştır. ${ }^{84} 72$ numaralı mühimme defterinde bunun örneklerini fazlasıyla görmekteyiz. ${ }^{85}$

XVI. yy. âid hükümlerin büyük kısmında gideceği yere ulaştırmak üzere kime ve hangi tarihte verildiğine de işaret olunmuştur. ${ }^{86} 72$ numaralı mühimme defterinde yer alan tarihlerin veriliş şekli çok fazla birbirini tutmamakla birlikte, hükümlerin birçoğunda tarih yazılmamıştır. ${ }^{87}$ Tarihlerin bir bölümünde Fî 9 R., ${ }^{88}$ Fî 19 M. ${ }^{89}$ şeklinde ayların rumuzları kullanılarak sene verilmeden yazılırken bir bölümünde $9 \mathrm{Ra}$ sene $3,{ }^{90} 17 \mathrm{Za}$ sene $1002^{91}$ şeklinde yılını vererek de yazmıştır.

Bir bölüm tarihlerde ise Yevm ü's-sülesâ Fî 24 Cemâzi-yel-evvel sene isneyn ve elf, ${ }^{92}$ Yevm-ü's-sebt Fî selh Recebü'l-âhir sene isneyn ve elf, ${ }^{93}$ Yevm ü's-sülesâ Fî 27 Rebîul-evvel sene isneyn ve elf gibi sene yazılırken rakam kullanmak yerine rakamlara karş1lik gelen Arapça kelimeler kullanılmıştır. ${ }^{94}$

Defterde tarih vermedeki bir diğer şekil de 15 Şa 'ban el-muazzam sene isneyn ve elf, ${ }^{95}$ Şa'ban el- muazzam sene isneyn ve elf, ${ }^{96} 7$ Recebü'l-mürecceb ${ }^{97}$ aylar sifatlariyla birlikte verilmiştir.

\section{DEFTERIN MUHTEVASI}

\subsection{EŞKIYALIK MESELELERI}

72 numaralı mühimme defterinde yer alan hükümlerin yarısına yakını Anadolu ve Rumeli'de meydana gelen eşkıyalık olayları ile ilgilidir. Çevrelerine topladıkları birkaç adamla özellikle yöneticiler ve diğer askeri kesimin seferde olduğu bölgelerde eşkıyalık

\footnotetext{
80 Hüküm 7.

81 Hüküm 278.

82 Hüküm 70, 284.

83 Hüküm 271.

${ }^{84}$ Mübahat S. Kütükoğlu, "Mühimme Defterlerindeki Muâmele Kayıdları Üzerine", Tarih Boyunca Paleografya ve Diplomatik Semineri, 30 Nisan-2Mayıs 1986, İstanbul 1988, s. 98

85 Hüküm 2, 9, 16, 28, 32, 61,

86 Kütükoğlu, a.g.m., s. 107

87 Hüküm 1, 3, 4, 5, 6, 8, 11, 40, 41, 43.

${ }^{88}$ Hüküm 61.

89 Hüküm 116.

90 Hüküm 9.

91 Hüküm 28.

92 Hüküm 42.

93 Hüküm 38 .

94 Hüküm 71.

95 Hüküm 158.

96 Hüküm 184.

97 Hüküm 129.
} 
yapan bazı kişiler; halkın erzaklarını ve hayvanlarını yağmalamakla yetinmemiş; onların ailelerine tasallutta bulunmuş ve ailelerini katletmişlerdir. ${ }^{98}$

Defterden anlaşıldığına göre eşkıyalık meselelerine toplumun bazı kesimlerinden insanlar katılmışlar ve devlet görevlileri de olayların faili olmuşlardır. Sancakbeyi, ${ }^{99} \mathrm{kad}_{1},{ }^{100}$ sekban ve yeniçeri, ${ }^{101}$ sahib-i tımar $^{102}$ ve reayadan ${ }^{103}$ kimselerin eşkıyalık olaylarına karıştıkları görülmekte; özellikle savaş dönemleri bu hadiselerin arttığı anlaşılmaktadır.

Bazı hükümler gösteriyor ki; eşkıyalık olayları halkı bıktırmış, isyan etmelerine ${ }^{104}$ veya vatanlarını terk etmelerine ${ }^{105}$ sebep olmuştur. Hiç şüphesiz eşkıyaların verdiği sıkıntının halk arasındaki acısını hafifletmenin ve devlet otoritesini temin etmenin en etkili yollarından birisi de eşkıya teftişi olmuştur. Osmanlı Devleti, herhangi bir havalideki eşkıyanın fesat ve eşkıyalıklarının önlenmesi için çoğu zaman güvendiği, daha önce devlete yararlı işlerde bulunan, bu konuda tecrübeli, yetenekli ve iş bitirir adamlarını bu bölgelere olağanüstü yetkilerle donatarak görevlendirmiştir. ${ }^{106}$ Yanına da o bölgeye yakın pek çok ehl-i örf, ehl-i şer', hatta aşiret veya cema'at boy beyleri görevlendirilmiştir. Geniş bir sahaya yayılan eşkıyalığın genel teftişi için ise vezir rütbeli paşalar görevlendirilmiştir. Devlet tarafindan bölge yöneticilerine gönderilen hükümlerde eşkıyaların ele getirilmesi davalarının şer'le hakk üzere çözümlenmesi ve haklarından kati surette gelinmesi emredilmiştir. ${ }^{107}$ Meydana gelen eşkıyalık olaylarını soruşturmak üzere görevlendirilen vali ve "müfettiş" vezir paşalara, başvuracakları tedbirlerin etkili olması için çok geniş yetkiler verilmiş ${ }^{108}$ ancak, devlet adına karar vermeye yetkili olan bu görevliler zaman zaman yetkilerini kötüye kullandıklarından, bu konuda sık sık uyarılırlar yapılmıştır. ${ }^{109}$ Eşkıyadan bazıları zaman zaman kendisine bir kefil tayin edilerek eşkıyalıktan uzaklaştırılmaya çalışılmış başarılamadığ çözümünde kefiller ön planda tutulmuş ve bulunup yakalanmalarında ki sorumluluk onlara yüklenmiştir. ${ }^{110}$ Eşkıyalık yapanlara verilen cezalar genel olarak "küreğe konulma"111,"haklarından gelinme"112, "kayd u bend ile",113 "mukayyed ve mahpus edilme" ${ }^{114} \mathrm{vb}$. şeklinde nitelendirilmiştir.

\subsection{BEÇ (VIYYANA) SEFERINE ASKER NAKLI}

Nakil ve haberleşme araçlarının tamamen insan ve hayvan gücüne dayalı olarak yürütüldügü bu dönemde muharip güçlerin teknik donanımı, talim ve disiplinlerinin yanı sıra

\footnotetext{
98 Hüküm 1, 2, 10, 23, 24, 30, 34.

99 Hüküm 186.

${ }^{100}$ Hüküm 15.

${ }^{101}$ Hüküm 28, 37, 51, 59, 64, 66, 119, 138, 156, 189.

102 Hüküm 40, 76, 88, 205, 226, 269.

${ }^{103}$ Hüküm 57, 64, 67, 70, 76, 108, 110, 206, 209, 212.

${ }^{104}$ Hüküm 7, 15, 26.

${ }^{105}$ Hüküm 220, 255, 302.

${ }^{106}$ Hüküm 189.

${ }^{107}$ Hüküm 18, 34, 36, 38, 40, 49, 57, 220, 224.

108 Hüküm 35, 257, 280.

${ }^{109}$ Hüküm 45, 73.

${ }^{110}$ Hüküm 47, 187, 251.

${ }^{111}$ Hüküm 539.

112 Hüküm 519.

${ }^{113}$ Hüküm 525.

${ }^{114}$ Hüküm 420.
} 
sefer öncesi yapılan hazırlıklar da çok büyük önemi arz etmiştir. Bu noktada tarih boyunca gücünü ordusundan ve bu ordunun savaşlarda sergilediği performanstan alan Osmanlı Devleti, varlığının ve gücünün sürekliliğini sağlayabilmek için yapacağı savaşlarda ordusunu seferlere en iyi şekilde hazırlamıştır.

Hükümlerde Beç üzerine açılan seferin seyri hakkında bilgi bulunmamasına rağmen garp cephesine askeri hazırlık ve sevkiyat hakkında çok fazla bilgi bulunmaktadır.

Avarız veya avarız-1 divâniye, Tanzimat'ın ilanına kadar, olağanüstü durumlarda ve özellikle harp masraflarını karşılamak üzere hükümdarın emri ile halkın doğrudan doğruya devlete vermeye mecbur tutulduğu her türlü hizmet, eşya ve para şeklindeki düzenli olmayan vergidir. ${ }^{115} \mathrm{Bu}$ dönemde de avarız vergisi toplanarak hazırlıklara başlanılmış; toplanan bu vergi birçok yerde fazladan toplanıldı̆̆ 1 içinde sıkıntılar baş göstermiştir. ${ }^{116}$

Devlet savaş hazırlığ içerisindeyken beylerbeylerine, sancakbeylerine ve voyvodalara hükümler gönderilerek sefere iktidarı olmayanların kale ve şehir muhafazalarına kalmalarını, iktidarı olanların asker, cebe, çüyuş ve at tedarikinde olmaları ve askerleriyle sefere varmaları emredilirken; ${ }^{117}$ diğer taraftan savaş alanında güçlü ve dirayetli askerler bulundurarak kendini garantiye almaya çalışmıştır. Savaşın seyrinde lazım olabilecek özellikle lağımcı ${ }^{118}$ ve geri hizmet elemanlar1 ${ }^{119}$ içinde yine emirler gönderilmiştir.

Kendi coğrafyasına çok iyi hakim olup en ince detayına kadar tanıyan Osmanlı yöneticileri, hazırlıklar tamamlandıktan sonra sefere varırken gidecekleri yolun güzergahına ve mola yerlerine kadar bildirilmiş, ${ }^{120}$ geçecekleri yerlerin yöneticilerine emirler yazılarak askerin ihtiyaçların karşılanması ve zorluk çektirilmemesi emredilirken meyhanelerin de kapatılması istenmiştir. ${ }^{121}$

Sefere gidip çeşitli sebeplerden dolayı görevlerini tamamlamadan dönenlerin, Anadolu'ya geçmelerinin engellenmesi ve cezalandırılmaları konusunda da emirler yazılmıştır. ${ }^{122}$

\section{3. İSTANBUL'A ZAHİRE NAKLI}

Osmanlı Devleti'ne çok uzun bir süre başkentlik yapmış olan İstanbul şehrinin iaşesini temin etmek, Osmanlı yöneticileri için her zaman en büyük problemlerden birisi olmuştur. İstanbul için takip edilen iaşeci politikada, Osmanlı sınırları içerisinde yapılan her türlü üretimin, üretim bölgelerindeki ihtiyaçlar giderildikten sonra arta kalan kısmının, öncelikli olarak İstanbul'a gönderilmesi zorunluluğu olmuştur. İaşe temini faaliyetlerinde, ilk olarak ihtiyaç duyulan ürün veya mallar tespit edilmiş, ardından bu ürün ve malların bulunduğu ve getirileceği sahalar belirlenmiştir. Bu işlem sonrasında ise, ürün veya malın getirileceği yerel birimle yazışmalar gerçekleştirilerek ürünün toplanma işi özel kişilere veya memurlara

115 Ömer Lütfi Barkan, “Avârız”, İslam Ansiklopedisi, C. II, Milli Eğitim Bakanlığı Yayınları, İstanbul 1993, s. 13.

${ }^{116}$ Hüküm 208, 231, 232, 269, 280.

${ }^{117}$ Hüküm 82, 92

${ }^{118}$ Hüküm 239.

${ }^{119}$ Hüküm 80.

${ }^{120}$ Hüküm 221.

${ }^{121}$ Hüküm 11, 86, 92, 125, 163, 221, 222, 239, 283, 300.

${ }^{122}$ Hüküm 13, 238. 
verilmiştir. ${ }^{123}$

72 numaralı defterde en çok rastlanan konulardan birisi de İstanbul'un zahiresinin karşılanması meselesidir. İstanbul'da gıda, kereste, yağ ve birçok meta sorunu çok büyük bir sorun olarak karşımıza çıkmaktadır. Osmanlı Devleti bu malzemelerin dışarı satılmasını engellemek için birçok önlem almışsa da; madrabaz denilen kimselerin, malı iskeleye gelmeden alıp depo edip, sonra azar azar yüksek fiyatla sattıkları görülmüştür. ${ }^{124}$

Defterde öne çıkan İstanbul'da et konusunda fazla sıkıntı çekildiğidir. Anadolu ve Rumeli'den İstanbul zahiresi için gönderilen koyunların gelmemesi üzerine yaşanan müzayaka için Erzurum, Diyarbakır, Selanik, Avrethisar ve Tercan koyunu bulunan cümle yerlere emirler gönderilerek; kadılar marifetiyle koyunların toplanması ve doğru İstanbul'a gönderilmesi emir olunmuştur. ${ }^{125}$ Ayrıca et konusunda istihdamın sağlanabilmesi ve çekilen sıkıntıların azaltılabilmesi için İstanbul'a dişi koyun gönderilmesini ve kesilmesini yasaklayan emirlerde mevcuttur. ${ }^{126}$

İstanbul buğday, un, kereste konusunda da dişa bağımlıdır ve bu konuda da sıkıntı çekilmiş, sıkıntıyı gidermek için emirler gönderilmiştir. Verilen talimatlar ile beraber ürünlerin dışarıya satılmasına engel olunarak İstanbul zahiresi için gönderilmesi emredilmiştir. ${ }^{127}$

İstanbul'un ihtiyaç duyduğu gıda maddelerinden bir diğeri de yağdır (revgan-1 sade). Kefe beyine ${ }^{128}$ ve Rumda vak1 ${ }^{6}$ olan kadılara ${ }^{129}$ gönderilen hükümlerde de bu konu dile getirilerek kadılar vasıtasıyla bu konunun çözülmesi emredilmiştir.

\subsection{VAKIFLARLA İLGİİ HUSULAR}

Vakıf, bireylerin kendi iradeleriyle toplumun ihtiyaçlarını karşılamak ve yardımlaşma amacıyla taşınır veya taşınmaz mallarını dinî, sosyal ve ekonomik bir gayeye hizmet etmeleri için tahsis etmesidir. ${ }^{130}$

Defterde vakıflarla alakalı birçok hüküm yer almaktadır; ${ }^{131}$ bunlar vergiden muaf halktan vergi alınmasından, ${ }^{132}$ evkaf mütevellisinin vakıf gelirinden kendi hesabına para aktarmasına $^{133}$ kadar birçok vakıf meselesinde hükümler bulunmaktadır. Bununla beraber Mekke ve Medine'ye gönderilen sürrelerin fukaraya ve hak sahibine dağıtılmaması; sürreye müstahak olanların zor durumlarda birakılması, sürresi olup vefat edenlerin sürrelerini başkalarının alması ${ }^{134}$ meseleleri de hükümler arasında yer almakta konu hakkında bilgi vermektedir.

\footnotetext{
${ }^{123}$ Cafer Çiftçi, “Osmanlı Döneminde İstanbul'un İâşesinde Bursa'nın Rolü”, Osmanlı Tarihi Araştırma ve Uygulama Merkez (OTAM) Dergisi, 2004, s. 154-156.

124 Hüküm 55, 202.

${ }^{125}$ Hüküm 12, 16, 106, 202.

${ }^{126}$ Hüküm 84, 85.

${ }^{127}$ Hüküm 17, 46, 63, 172.

${ }^{128}$ Hüküm 256.

${ }^{129}$ Hüküm 6.

${ }^{130}$ Abdullah Saydam, Osmanlı Medeniyeti Tarihi, Kitapevi Yay., İstanbul 2017, s. 237-238.

${ }^{131}$ Hüküm 332, 333, 334, 377, 409, 450, 454, 495, 592, 619.

132 Hüküm 18, 29.

${ }^{133}$ Hüküm 68.

${ }^{134}$ Hüküm 93, 94, 95, 129, 148.
} 
Defterdeki vakıflar ile ilgili hükümler; "evkâfindan bir miktar akçe karz tarîkiyle alduğun 135", "vakfin mahsulün alup ekl idüb ve vakfîharâb ve müşrif olmuştur ${ }^{136 ” " v e ~}$ "evkâfin malına nazırları ve mütevellileri ekl ve bel' etmekle 137 " şeklinde ifade edilmiştir. Defterde vakıflar ile alakalı geçmiş olan bir olay da Amasya'da Sultan Alaaddin tarafindan yaptırılan bimarhanenin toprağının vakıf olduğu fakat bu vakfın bir kısmının tımar olarak kullanılmış olduğunun tespit edilmesidir. Bu olay Amasya Beyi ve kadısına gönderilen emir neticesinde düzeltilmeye çalışılmış, toprağın hepsinin vakıf olarak kullanılması talimatı verilmiştir. ${ }^{138}$ Defterdeki bahsi geçen bu durumdan Osmanlı Devleti'nin vakıflara ayrı bir önem verdiğini yönünde çıkarım yapılabilir.

\subsection{SERHAD KALELERININ TAMIR, TAHKIM VE MUHAFAZASI}

72 numaralı mühimme defterinde Osmanlı-Safevi ilişkilerini anlatan hükümleri görmek mümkündür. ${ }^{139}$ Özellikle iki devlet arasında yaşanan sınır ihlallerine değinilmiştir. ${ }^{140}$ Bundan dolayı sınır şehirlerinin korunması, ${ }^{141}$ kalelerin bakım ve tamiri ${ }^{142}$ önemli bir durum olarak ortaya çıkmıştır. Özellikle de Şirvan, Kars, Gori, Tebriz, Bağdat kalelerinin tamiri emredilmiştir.

Kaytak Hâkimine gönderilen hükümde Rus keferesin yirmi bin kadar askerle gelerek Dağıstan hâkimi Şimhal'ın ülkesine iki yerde kale yapıp içlerine beş altı binden fazla silahlı kâfir konduğu tespit edildiği bilgisi verilmiştir. Gönderilen hüküm de Kaytak Hâkimi ve Dağıstan hâkimi Şimhal'ın memleketlerini koruyup muhafaza etmelerinin önemli olduğu vurgulanmıştır. Ayrıca Rus keferesinin yaptırdığı bu iki kalenin yıkılması emredilmiştir. ${ }^{143}$

Kefe Beylerbeyisine gönderilen bir hüküm ise Gözlü Kalesinin korunmasının önemli olduğu belirtilerek Özi ve Akkerman'da bulunan iki kıta kadırgayı donatıp kalenin muhafazası için kullanılması emredilmiştir. ${ }^{144}$

Yemenin muhfazası ile görevlilere gönderilen bir hüküm de ise muhafaza için asker ve at tedarik edilmesinin mühim olduğu ve bu iş için özverili bir şekilde çalışılması gerektiği emredilmiştir. $^{145}$

Sadrazam tarafindan yazılan bir hüküm de ise Estergon, Tatvan kalelerinin muhasara üzere oldukları belirtilmiştir. Sefer sırasında Kırım Hanına gönderilen tuğralı nâme-i hümâyunlarda Hanın kadırga ve kalitalarla ${ }^{146}$ Karadeniz'e açılması istenmiştir. Ayrıca askerin ulufesi için Mısır defterdarına tuğralı fermanların gönderildiği de bildirilmiştir. ${ }^{147}$

\footnotetext{
${ }^{135}$ Hüküm 332.

${ }^{136}$ Hüküm 333.

${ }^{137}$ Hüküm 409 .

${ }^{138}$ Hüküm 450.

${ }^{139}$ Hüküm 309, 310, 319, 344, 347, 369, 397, 411, 437, 565, 566, 599, 600.

${ }^{140}$ Hüküm 311, 343, 444, 464, 476, 478, 497, 500, 576, 584, 604, 628.

${ }^{141}$ Hüküm 313, 337, 342, 360, 387, 389, 420, 423, 427, 441, 458, 506, 513, 514, 530, 531, 543, 567, 598, 608, $610,615,616,629$.

${ }^{142}$ Hüküm 320, 392, 419, 564, 585.

${ }^{143}$ Hüküm 464.

${ }^{144}$ Hüküm 482.

${ }^{145}$ Hüküm 615.

${ }^{146}$ Kalita: 19 ile 24 arası oturağa sahip çektiri tarzı savaş gemilerine verilen isimdir. Uzunçarşılı, a.g.e., s. 460.

${ }^{147}$ Hüküm 604.
} 


\subsection{DİĞER MESELELER}

Defterde oldukça fazla bulunan benzer hükümler dışında bir veya birkaç hüküm şeklinde yazılmış hükümlerde vardır.

$\mathrm{Bu}$ dönemde vukuu bulan Osmanlı-Safevi savaşında Bağdat muhafazasına tayin olan Vezir Hızır Paşa'ya gereksiz sancak tevcih etmemesi, asker ulufelerinin ödenmesi ${ }^{148}$ konularında hükümler gönderilmiştir. Ayrıca diğer beylerbeylerine Şirvan'a ${ }^{149}$ yardıma gitmeleri için emirler yazılmıştır.

Defterde Anadolu ve Rumeli bölgelerine görevlendirilen kâtip, defterdar, bevvaban ${ }^{150}$ ve diğer görevlilerin yollarda hiçbir şeye sıkıntı çektirilmemesi ve menzillerde ulak ve kılavuz tayin edilmesi, ${ }^{151}$ devletin hemen her kademesine yapilan tayinler ve aziller, ${ }^{152}$ o sirada gönderilen Leh elçisinin sağ salim ülkesine intikali, ${ }^{153}$ menzil bargirlerinin tedariki ve tahsisi, ${ }^{154}$ zimmetlerinde devlet malı bulunanlardan zararın tanzim edilmesi, ${ }^{155}$ Özi ve deniz muhafazasında olan gemilerin Rodos'da ziyade zaman tüketmemeleri, ${ }^{156}$ madrabazların karaborsa oluşturmamaları ${ }^{157}$ halkın su ihtiyacının karşılanmas $1^{158}$ hususlarında ve buna benzer birçok hususta hükümler yer almaktadır.

\section{SONUÇ}

Osmanlı Devleti, bugünün müessese anlayışının oluşmasına yüzyıllar öncesinden öncülük etmiş, kuruluş yıllarından itibaren milyonlarca arşiv belgesini muhafaza ederek devlet geleneğinde devamlılığı sağlamış ve sistemini yüzyıllarca işletebilmiştir. Bu devredilen miras arşivlerin, en önemlilerini üst düzey karar organı olan; Divân-1 Hümâyun' da tutulan defterler ihtiva etmektedir. Divân-1 Hümâyun, merkezdeki siyasî, sosyal, hukukî, iktisadî, idarî konularda alınan kararların tutulduğu bu defterlerin en önemlilerinden biri de şüphesiz ki mühimme defterleridir.

Birinci el kaynak olarak nitelendirilen bu defterler üzerindeki çalışmalar, Başbakanlık Osmanlı Arşivi'nin yanı sıra, son dönemlerde bazı üniversitelerde de oldukça yoğunlaşmıştır. Bunlar tamamlandığı takdirde tarih araştırmacılarına çok büyük kolaylık sağlanacaktır.

72 numaralı Mühimme Defteri Sultan III. Murad dönemine ait olup muhteva bakımından Osmanlı Devleti'nin merkez ve taşra teşkilatındaki idari ve askeri organların yapısını, karşılıklı münasebetlerini, Osmanlı Devleti'nin işleyişini anlama da, ayrıca komşu ülkeler, gayrimüslim devletler ile olan münasebetleri, azınlıkların hukukunu, halkın sosyal ve ekonomik durumunu, hac organizasyonlarını, belediye işleri ve askeri tarih konularını, lojistik hizmetler, ağırlıklı olarak eşkıyalık olaylarını, sefer hazırlıklarını, İstanbul'a zahire nakli ve

\footnotetext{
148 Hüküm 11, 46, 60.

${ }^{149}$ Hüküm 179, 241, 242, 244.

${ }^{150}$ Bevvâbân: Kapıcılar. Ferit Devellioğlu, Osmanlıca-Türkçe Ansiklopedik Lügat, Aydın Kitabevi, Aydın 2009,s.136

${ }^{151}$ Hüküm 96, 205.

152 Hüküm 8, 32, 35, 56, 59, 103.

${ }^{153}$ Hüküm 267, 270.

${ }^{154}$ Hüküm 65, 107, 117, 260.

${ }^{155}$ Hüküm 72, 142, 147.

${ }^{156}$ Hüküm 36.

${ }^{157}$ Hüküm 55.

${ }^{158}$ Hüküm 56.
} 
daha birçok konuya değinen birinci elden kaynak olma özelliğine sahiptir. Bu çalışmada ise defterin özellik ve içerik bakımından yapılmıştır. Osmanlı bürokrasisinin de önemli bir yeri olan Mühimme Defterleri, muhtevası itibarıyla son derece zengin tarihi bilgiye sahiptirler ve araştırmacılar için önemli bir kaynak olma özelliklerini sürdürmektedirler. Konu alınan 72 numaralı Mühimme Defteri de bu zenginliğin bir parçasını oluşturmaktadır. Araştırmalarda öncülük edecek ve tarihin bazı sayfalarının aydınlanmasında yardımcı olabilecek bu birinci elden kaynak hazırlanıp; faydalanılabilecek duruma getirilmeye çalışılmıştır. 


\section{KAYNAKÇA}

Arşiv Kaynakları

A.DVN.MHM. d.072

3 Numaralı Mühimme Defteri (966-968/i 558-i 560), T.C. Başbakanlık, Devlet Arşivleri Genel Müdürlüğü Ankara 1993.

44 Numaralı Mühimme Defteri, Haz: Mehmet Ali Ünal, Akademi Kitabevi Yay., İzmir 1995.

\section{Araştırma-İnceleme Eserler}

AHISHALI, Recep, “Divân-1 Hümâyûn Teşkilatı”, Osmanlı, C. IV, Yeni Türkiye Yay., Ankara 1999, ss.24-33

BARKAN, Ömer Lütfi, "Avârız”, İslam Ansiklopedisi, C.II, Milli Eğitim Bakanlığı Yayınları, İstanbul 1993.

Başbakanlık Osmanlı Arşivi Rehberi, İstanbul, 2002.

ÇİFTÇİ, Cafer, “Osmanlı Döneminde İstanbul'un İâşesinde Bursa'nın Rolü” Osmanlı Tarihi Araştırma ve Uygulama Merkez (OTAM) Dergisi, 2004, ss.151-171.

DEVELLIOĞLU, Ferit, Osmanlıca-Türkçe Ansiklopedik Lügat, Aydın Kitabevi, Aydin 2009.

EMECEN, Feridun, “Ali’nin ‘Ayn'1: XVII. yüzyıl başlarında Osmanlı Bürokrasisinde Katib Rumuzları”, Osmanlı Klasik Çağında Hanedan Devlet ve Toplum, Timaş Yayınları, İstanbul 2011.

EMECEN, Feridun, "Osmanlı Divânını Ana Defter Serileri: Ahkâ-Miri, Ahkâm-1 Kuyudu Mühimme ve Ahkâm-1 Şikâyet", Türkiye Araştırmaları Literatür Dergisi, C. 3, S.5, 2005, ss. 107-139.

HALAÇOGLU, Yusuf, XIV. ve XVII. Yüzyıllarda Osmanlılarda Devlet Teşkilâtı ve Sosyal Yapı, TTK., Ankara 1994.

KÜTÜKOĞLU, Mübahat S., “Mühimme Defterlerindeki Muâmele Kayıdları Üzerine”, Tarih Boyunca Paleografya ve Diplomatik Semineri, 30 Nisan-2 Mayıs 1986, İstanbul 1988, ss. 95-113

KÜTÜKOĞLU, Mübühat S., Osmanlı Belgelerini Dili (Diplomatik), Kubbealtı Neşriyatı Yay., İstanbul 1994.

MİROĞLU, İsmet, "Mühimme Defterleri”, Tarih ve Medeniyet Dergisi, S.12, İstanbul 1993, s.58-64.

MUMCU, Ahmet, "Divân-1 Hümâyun", DİA, C. IX, Türkiye Diyanet Vakfi Yay., İstanbul

1994. 
MUMCU, Ahmet, Divan-ı Humayun, Birey ve Toplum Yay., Ankara 1986.

PAKALIN, M. Zeki, Osmanlı Tarih Deyimleri ve Terimleri Sözlüğü, C.II, İstanbul 1993.

SAYDAM, Abdullah, Osmanlı Medeniyeti Tarihi, Kitapevi Yay., İstanbul 2017.

SELANÎKI, Mustafa Efendi, Tarih-i Selanik-i, C. II, (Haz. Mehmet İpşirli), TTK Yay., Ankara 1999.

SELÇUK, Demir, 75 Numaralı Mühimme Defteri, (Yayınlanmamış Yüksek Lisans Tezi), Atatürk Üniversitesi Sosyal Bilimler Enst., Erzurum 2008,

UZUNÇARŞILI, İsmail Hakkı, Osmanlı Devleti'nin Merkez ve Bahriye Teşkilatı, TTK. Yay., Ankara 1988. 